\title{
ANALISIS KARAKTERISTIK RUMAH DI KOTA MEDAN TERHADAP PEDOMAN TEKNIS RUMAH DAN BANGUNAN GEDUNG TAHAN GEMPA
}

\author{
Bambang Hadibroto \\ Dosen Pengajar Jurusan Pendidikan Teknik Bangunan, Fakultas Teknik, UNIMED, Medan \\ Surel : hadibroto@unimed.ac.id \\ Diterima : 26 November 2017; Disetujui : 30 November 2017
}

\begin{abstract}
ABSTRAK
Sumatera Utara adalah salah satu provinsi yang memiliki potensi bencana gempa yang tinggi. Sejarah membuktikan bahwa sejumlah gempa kuat pernah mengguncang beberapa kawasan di provinsi ini dan mengorbankan ramai jiwa manusia. Perkembangan ekonomi yang terus meningkat di kota Medan mengakibatkan meningkat pula pertumbuhan rumah sebagai lokasi tempat tinggal. Pertumbuhan rumah ini tidak seiring dengan perkembangan program mitigasi gempa khususnya yang terkait dengan tata ruang dan mengikuti kaedah rekayasa yang teliti dan kode peraturan yang berlaku. Bisa jadi rumah ini dibuat dengan perencanaan yang mengesampingkan perhitungan analisa struktur. Kondisi ini akan menyebabkan rumah yang tumbuh menjamur di kota Medan menjadi rentan terhadap bencana gempa. Kerentanan akan semakin tinggi pada kawasan-kawasan yang secara geografis terletak pada daerah rawan gempa yang tinggi. Studi ini dilakukan untuk mengetahui karakteristik dan mutu konstruksi rumah di kota Medan berdasarkan persepsi penghuni rumah dan bagaimanakah kualitas konstruksi rumah di kota Medan berdasarkan karakteristik dengan pedoman teknis rumah dan bangunan gedung tahan gempa. Metode penelitian yang digunakan adalah analisis documentary historical, survey dan observasi. Hasil dari studi ini menunjukkan bahwa karakteristik rumah di kota Medan adalah rumah semi permanen dan rumah permanen. Rumah semi permanen merupakan rumah kayu melayu deli dan rumah panggung melayu deli 2 lantai yang telah di modifikasi. Rumah permanen merupakan rumah tembokan 1 lantai, 2 lantai dan rumah mewah. Kualitas elemen struktur berdasarkan persepsi penghuni rumah berdasarkan persyaratan tahan gempa adalah penutup atap rata-rata $88,74 \%$. Untuk elemen perkuatan struktur yaitu pondasi rata-rata sebesar $70,57 \%$ dan kelengkapan struktur sloof, balok dan kolom serta proporsi campurannya rata-rata $67,60 \%$. Kualitas dinding rata-rata $77,14 \%$.
\end{abstract}

Kata Kunci : documentary historical, karakteristik, rumah, survey, observasi

\section{Pendahuluan}

Rumah adalah bangunan yang berfungsi sebagai tempat tinggal atau hunian dan sarana pembinaan keluarga. Jadi, selain berfungsi sebagai tempat tinggal atau hunian yang digunakan untuk berlindung dari gangguan iklim dan makhluk hidup lainnya, rumah merupakan tempat awal pengembangan kehidupan (Yudohusodo, 1991). Dalam UU No. 4 Tahun 1992 tentang Rumah dan Permukiman, rumah diartikan sebagai bangunan yang berfungsi sebagai tempat tinggal atau hunian dan sarana pembinaan keluarga.

Rumah adalah bagian yang utuh dari permukiman, dan bukan hasil fisik sekali jadi semata, melainkan merupakan suatu proses yang terus berkembang dan terkait dengan mobilitas sosial ekonomi penghuninya dalam suatu kurun waktu. Perioritas utama rumah adalah dampak terhadap penghuni, bukan wujud atau standar fisiknya. Interaksi antara rumah dan penghuni adalah apa yang diberikan rumah kepada penghuni serta apa yang dilakukan penghuni terhadap rumah (Turner, 1972).

Kota Medan merupakan salah satu kota ke-3 terbesar di Indonesia setelah Jakarta dan Surabaya. Dan merupakan salah satu kotamadya dari 33 kabupaten/kota di Provinsi Sumatera Utara. Menurut data pusat statistik tahun 2015 kota Medan mengalami perkembangan yang sangat pesat dari jumlah penduduk dan perumahan. Luas wilayah kota medan $265 \mathrm{~km} 2$ dengan jumlah penduduk 2.210.624 jiwa dan kepadatan penduduk 8.342 jiwa/km2. Luas wilayah yang kecil tersebut 


\section{Bambang Hadibroto}

dibagi menjadi 21 kecamatan. Dengan pertumbuhan penduduk yang tinggi tersebut dibarengi dengan pertumbuhan rumah yang tinggi. Hal ini dapat dilihat dari data statistik perumahan tahun 2014 tentang persentase rumah tangga menurut jenis lantai terluas yaitu sebesar $\quad 50,87 \%$ untuk lantai marmar/granit/kramik 47,01\% untuk lantai tegel/traso dan 2,12\% untuk lantai kayu/tanah. Bagus dan indahnya pandangan luar suatu perumahan tidak menjamin mutu dan kualitas bangunannya juga bagus. Mutu dan kualitas suatu bangunan perumahan diketahui setelah penghuninya menempati bangunan perumahan tersebut. Hal-hal yang mempengaruhi kekuatan struktur bangunan dipengaruhi oleh desain mekanika struktur yang berkaitan dengan kestabilan struktur termasuk desain pondasinya, mutu bahan atau material, cara pelaksanaan konstruksi serta operasional dan pemeliharaan. Menilai suatu konstruksi bangunan dapat dikatakan bagus atau tidak jika desainnya sudah memenuhi ketentuan yang sudah berlaku atau peraturanperaturan yang berlaku, maka selanjutnya perlu dilihat mutu bahan atau materialnya. Dan yang terpenting juga adalah bagaimana pelaksanaannya di lapangan. Terkadang pelaksanaan di lapangan dihadapkan pada kompleksitas lingkungan dan kondisi sumber daya manusia seperti tukang atau pekerja di lapangan (Basuki, 2009).

Dengan perkembangan ekonomi yang terus meningkat di Sumatera Utara, pertumbuhan perumahan sebagai lokasi tempat tinggal ikut meningkat pula di kota Medan. Sayangnya pertumbuhan perumahan ini tidak seiring dengan perkembangan program mitigasi gempa khususnya yang terkait dengan tata ruang dan penerapan/penegakan aturan main dalam pembangunan fisik bangunan dan infrastruktur. Sudah menjadi rahasia umum bahwa perumahan di kota Medan tidak direncanakan secara layak mengikuti kaedah rekayasa yang teliti dan kode peraturan yang berlaku. Bisa jadi perumahan ini dibuat dengan perencanaan yang mengesampingkan perhitungan analisa struktur. Kondisi ini akan menyebabkan perumahan yang tumbuh menjamur di kota Medan menjadi rentan terhadap bencana gempa. Kerentanan akan semakin tinggi pada kawasan-kawasan yang secara geografis terletak pada daerah rawan gempa yang tinggi.

Permasalahan yang ada adalah bagaimanakah karakteristik rumah di kota Medan berdasarkan kesesuaian dengan persyaratan tahan gempa. Dilatar belakangi hal tersebut, perlu dilakukan penelitian tentang analisis karakteristik rumah di kota Medan berdasarkan kesesuaian dengan persyaratan tahan gempa. Pengukuran kesesuaian dengan persyaratan berdasarkan pedoman teknis rumah dan bangunan gedung tahan gempa. Hasil penelitian ini diharapkan dapat dijadikan masukan dalam peningkatan kualitas rumah di kota Medan sekaligus memenuhi kinerja konstruksi tahan gempa

\section{Kajian Pustaka}

Dalam Pasal 1 Undang-Undang Nomor 4 Tahun 1992 menyebutkan bahwa rumah adalah bangunan yang berfungsi sebagai tempat tinggal atau hunian dan sarana pembinaan keluarga; Rumah adalah kelompok rumah yang berfungsi sebagai lingkungan tempat tinggal atau lingkungan hunian yang dilengkapi dengan prasarana dan sarana lingkungan; sedangkan Permukiman adalah bagian dari lingkungan hidup di luar kawasan lindung, baik yang berupa kawasan perkotaan maupun perdesaan yang berfungsi sebagai lingkungan tempat tinggal atau lingkungan hunian dan tempat kegiatan yang mendukung perikehidupan dan penghidupan.

Rumah bukan hanya sekedar untuk menghindarkan hujan dan panas, melainkan rumah mampu memberikan ketenangan, kesenangan, bahkan kenangan akan segala peristiwa hidupnya. Disini harus mengetahui situasi dan kondisi setempat, baik secara alami atau secara formal akibat adanya peraturan dan persyaratan yang berlaku pada wilayah itu. Jika suatu perencanaan tidak memperhatikan situasi dan kondisi sertaperaturan/persyaratan yang berlaku, maka besar kemungkinan justru akan menyimpang dari tujuan pokok pembangunan rumah sebagai sarana kehidupan yang memerlukan suasana nyaman, tenang, indah, sehat dan aman (Surowiyono, 1996).

\subsection{Persyaratan Rumah}

Dalam penentuan lokasi suatu rumah, perlu adanya suatu kriteria atau persyaratan untuk menjadikan suatu lokasi sebagai lokasi rumah. Kriteria tersebut antara lain :

1) Tersedianya lahan yang cukup bagi pembangunan lingkungan dan dilengkapi dengan prasarana lingkungan, utilitas umum dan fasilitas sosial.

2) Bebas dari pencemaran air, pencemaran udara dan kebisingan, baik yang berasal dari sumber daya buatan atau dari sumber daya alam (gas beracun, sumber air beracun, $\mathrm{dsb})$. 


\section{Analisis Karakteristik Rumah Di Kota Medan TerhadapPedoman Teknis Rumah Dan Bangunan Gedung Tahan Gempa}

3) Terjamin tercapainya tingkat kualitas lingkungan hidup yang sehat bagi pembinaan individu dan masyarakat penghuni.

4) Kondisi tanahnya bebas banjir dan memiliki kemiringan tanah 0-15\%, sehingga dapat dibuat sistem saluran air hujan (drainase) yang baik serta memiliki daya dukung yang memungkinkan untuk dibangun rumah.

5) Adanya kepastian hukum bagi masyarakat penghuni terhadap tanah dan bangunan diatasnya yang sesuai dengan peraturan perundang-undangan yang berlaku, yaitu :

$>$ Lokasinya harus strategis dan tidak terganggu oleh kegiatan lainnya.

$>$ Mempunyai akses terhadap pusatpusat pelayanan, seperti pelayanan kesehatan, perdagangan, dan pendidikan.

$>$ Mempunyai fasilitas drainase, yang dapat mengalirkan air hujan dengan cepat dan tidak sampai menimbulkan genangan air.

$>$ Mempunyai fasilitas penyediaan air bersih, berupa jaringan distribusi yang siap untuk disalurkan ke masingmasing rumah.

$>$ Dilengkapi dengan fasilitas pembuangan air kotor, yang dapat dibuat dengan sistem individual yaitu tanki septik dan lapangan rembesan, ataupun tanki septik komunal.

$>$ Permukiman harus dilayani oleh fasilitas pembuangan sampah secara teratur agar lingkungan permukiman tetap nyaman.

> Dilengkapi dengan fasilitas umum, seperti taman bermain untuk anak, lapangan atau taman, tempat beribadah, pendidikan dan kesehatan sesuai dengan skala besarnya permukiman tersebut.

$>$ Dilayani oleh jaringan listrik dan telepon.

\section{Metodologi}

\subsection{Metode Pengambilan sampel Data}

Populasi dalam penelitian adalah sampel rumah di kota Medan, sampel terdiri dari rumah di 7 kecamatan yang ada di kota Medan, setiap kecamatan ada 10 responden rumah.

Pengambilan data dilakukan melalui :

a. Survey adalah suatu metode pengumpulan data yang menggunakan kuisioner atau wawancara. b. Observasi metode ini ditujukan untuk menilai situasi dan kondisi berkaitan kondisi pembangunan dilapangan.

\subsection{Metode Analisis}

Metode analisis yang digunakan dalam penelitian ini mengacu pada Evita (2011) yaitu :

1) Documentary Historical.

Jenis data yang digunakan dalam metode ini adalah data-data publik (media massa, kepustakaan, arsip-arsip dan sebagainya).

2) Survey suatu metode pengumpulan data yang menggunakan kuisioner atau wawancara. Wawancara dilakukan untuk menggali karakteristik rumah dan kebiasaan masyarakat membangun rumah.

3) Observasi

Metode ini ditujukan pada rumah-rumah masyarakat yang ada di kota Medan untuk mengetahui karakteristik rumah dan kebiasaan masyarakat membangun rumah

\subsection{Diagram Alir Penelitian}

Penelitian dibuat berdasarkan gambar flowchart dan penjelasan di bawah ini :

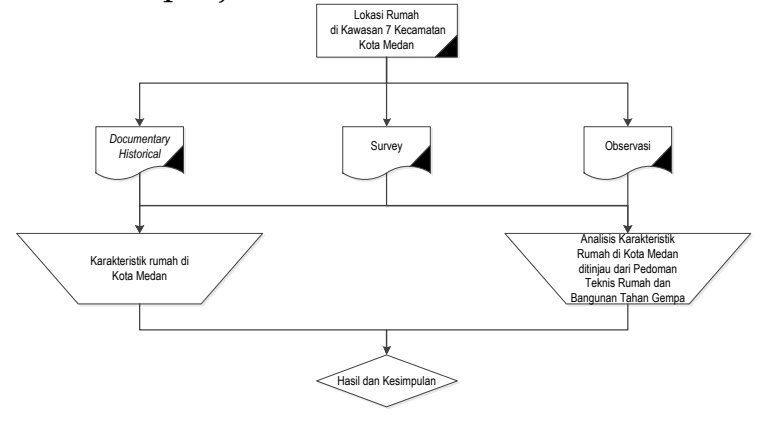

Gambar 1. Bagan alir metodologi

\section{Hasil dan Pembahasan}

\subsection{Tipe Rumah}

Konsep bangunan tahan gempa pada dasarnya adalah upaya untuk membuat seluruh elemen rumah menjadi satu kesatuan yang utuh, yang tidak lepas atau runtuh akibat gempa. Tetapi pada skala tertentu jika memang bangunan tersebut akan roboh karena kekuatan gempa yang besar, paling tidak bangunan tersebut masih mempunyai waktu untuk bertahan dari goncangan untuk memberikan waktu kepada penghuninya menyelamatkan diri dan mengevakuasi anggota keluarga yang lain.

Berdasarkan hasil survey dan observasi yang dilakukan pada sample rumah di 7 kecamatan yang ada di Kota Medan dengan membatasi pada bahan material dinding rumah terdapat 2 
tipe rumah yaitu : rumah semi permanen dan rumah permanen.

1. Rumah Semi Permanen

a. Rumah Kayu Melayu Deli

Rumah konstruksi kayu adalah bangunan rumah dengan menggunakan sistem struktur rangka pemikul dari bahan kayu. Biasa disebut sebagai rumah kayu, ciri-cirinya yaitu seluruh komponen balok dan kolom serta dinding yang digunakan adalah kayu. Rumah dengan struktur rangka kayu harus menggunakan sambungansambungan takik yang dikencangkan dengan menggunakan paku minimal 4 buah. Rumah Melayu adalah Rumah kayu atau rumah kampung pada suatu masa dulu boleh dikatakan tidak asing bagi orang Melayu. Tapi dengan urbanisasi penduduk kini, ramai anakanak Melayu yang tidak lagi mengenal apakah ciri bentuk sebenarnya rumah kayu tradisional maupun caranya dibangun tanpa paku. Rumah Melayu merupakan sebuah rumah yang dibangun dan dihuni oleh orang melayu. Tipe rumah melayu termasuk kategori bangunan semi permanen, yang terdiri dari tiga jenis, yaitu rumah tiang enam, rumah tiang enam berserambi, dan rumah tiang dua belas, atau rumah serambi. Rumah tiang dua belas atau rumah serambi merupakan rumah besar dengan tiang induk sebanyak dua belas buah. Rumah melayu adalah rumah panggung atau berkolong, dan memiliki tiang-tiang tinggi.

Karakteristik struktur rumah kayu melayu deli adalah :

1) Atap yang digunakan : sebagian besar menggunakan seng sangat jarang yang masih menggunakan rumbia (daun nipah), namun ada juga yang menggunakan genteng.

2) Kusen-kusen, daun pintu dan jendela terbuat dari panel kayu dan ada juga yang menggunakan panel kayu dengan kaca.

3) Lantai rumah panggung terbuat dari kayu, sedangkan rumah kayu diatas tanah lantainya cor beton kasar dan ada juga yang masih menggunakan lantai tanah.

4) Pondasi rumah panggung merupakan pondasi tiang kayu yang ditancapkan kedalam tanah, namun ada juga yang menggunakan pondasi tapak. Sedangkan rumah kayu di atas tanah menggunakan pondasi kayu yang ditanam di dalam tanah. Bentuk rumah simetris dan sederhana dengan bentuk bujur sangkar atau persegi panjang.

b. Rumah Panggung Melayu Deli 2 Lantai, Rumah setengah batu dan setengah kayu.

Rumah jenis ini merupakan rumah panggung yang dimodifikasi, dimana lantai bawah menggunakan pasangan bata dan bagian atas dari kayu. Rumah ini awalnya merupakan rumah panggung kayu, yang lantai bawahnya kemudian dipasang dinding dan sekatsekat ruangan untuk keperluan tambahan ruangan bagi sebuah keluarga atau untuk usaha. Jika tambahan pasangan dinding menggunakan konstruksi beton bertulang dan perbaikan pondasi beton rumah ini juga dapat dimasukkan kedalam rumah permanen. Rumah jenis ini merupakan rumah sederhana.

Karakteristik struktur rumah panggung melayu deli 2 lantai adalah :

1) Atap yang digunakan : sebagian besar menggunakan seng sangat jarang yang masih menggunakan rumbia (daun nipah), namun ada juga yang menggunakan genteng.

2) Kusen-kusen, daun pintu dan jendela terbuat dari panel kayu dan ada juga yang menggunakan panel kayu dengan kaca.

3) Lantai rumah panggung terbuat dari kayu, sedangkan rumah kayu diatas tanah lantainya cor beton kasar dan ada juga yang masih menggunakan lantai tanah.

4) Pondasi rumah panggung merupakan pondasi tiang kayu yang ditancapkan kedalam tanah, namun ada juga yang menggunakan pondasi tapak. Sedangkan rumah kayu di atas tanah menggunakan pondasi kayu yang ditanam di dalam tanah. Bentuk rumah simetris dan sederhana dengan bentuk bujur sangkar atau persegi panjang.

\section{Rumah Permanen}

\section{a. Rumah Mewah}

Rumah jenis ini termasuk rumah tembokan 1 lantai, 2 lantai dan termasuk rumah mewah. Sedangkan karakteristik rumah mewah adalah : 


\section{Analisis Karakteristik Rumah Di Kota Medan TerhadapPedoman Teknis Rumah Dan Bangunan Gedung Tahan Gempa}

1) Atap yang digunakan : sebagian besar menggunakan genteng, namun sudah banyak yang menggunakan atap metal (metal roof).

2) Kusen-kusen, daun pintu dan jendela terbuat dari panel kayu dan ada juga yang menggunakan panel kayu dengan kaca.

3) Lantai rumah sudah menggunakan keramik

4) Pondasi yang digunakan adalah pondasi menerus batu kali dan umumnya sudah menggunakan balok sloof.

5) Dindingnya terbuat dari batu bata

6) Bentuk rumah tidak simetris.

\subsection{Analisis Karakteristik Konstruksi Berdasarkan Kesesuaian Persyaratan Tahan Gempa}

Tabel 1. Persentase Rata-rata Kualitas Elemen Struktur

\begin{tabular}{|c|c|c|}
\hline Kode & Indikator & $\begin{array}{l}\text { Persentase } \\
\text { Rata-rata } \\
\text { Kualitas } \\
\text { Elemen } \\
\text { Struktur } \\
\text { Berdasarkan } \\
\text { Persepsi } \\
\text { Konsumen } \\
(\%) \\
\end{array}$ \\
\hline 1 & $\begin{array}{l}\text { Struktur pondasi } \\
\text { dan perkuatannya }\end{array}$ & 70,57 \\
\hline 2 & $\begin{array}{l}\text { Kelengkapan } \\
\text { struktur sloof, } \\
\text { balok, dan kolom } \\
\text { serta proporsi } \\
\text { campurannya }\end{array}$ & 67,60 \\
\hline 3 & Lantai & 80,26 \\
\hline 4 & Dinding & 77,14 \\
\hline 5 & Plafon & 70,23 \\
\hline 6 & Penutup Atap & 88,74 \\
\hline 7 & Kusen & 74,06 \\
\hline 8 & Pintu & 81,63 \\
\hline 9 & Jendela & 77,09 \\
\hline 10 & $\begin{array}{l}\text { Instalasi listrik dan } \\
\text { Kelengkapannya }\end{array}$ & 86,80 \\
\hline 11 & Kamar Mandi & 82,89 \\
\hline 12 & $\begin{array}{l}\text { Kelengkapan } \\
\text { instalasi air bersih } \\
\text { dan air kotor }\end{array}$ & 84,06 \\
\hline 13 & Saluran Drainase & 80,00 \\
\hline 14 & Septi Tank & 78,83 \\
\hline
\end{tabular}

Tabel 2. Karakteristik Kualitas Konstruksi

\begin{tabular}{clc}
\hline No. & Kecamatan & $\begin{array}{c}\text { Kualitas } \\
\text { Konstruksi } \\
(\mathbf{0})\end{array}$ \\
\hline 1 & Medan Johor & 84,22 \\
\hline 2 & Medan Tembung & 76,16 \\
\hline 3 & Medan Perjuangan & 77,35 \\
\hline 4 & Medan Timur & 85,47 \\
\hline 5 & Medan Helvetia & 67,66 \\
\hline 6 & Medan Sunggal & 78,74 \\
\hline 7 & Medan Denai & 84,53 \\
\hline & Rata-rata & 79,16 \\
\hline
\end{tabular}

Hasil analisis karakteristik pekerjaan dengan persyaratan tahan gempa sebagai berikut:

1) Pekerjaan Kolom

a. Ukuran kolom minimal $12 \times 12 \mathrm{~cm}$.

b. Tebal selimut beton $2.5 \mathrm{~cm}$.

c. Diamater minimum tulangan utama yang digunakan adalah $12 \mathrm{~mm}$.

d. Jarak sengkang pada daerah tumpuan lebih rapat dari pada sengkang pada daerah tengah bentang (jarak $<15 \mathrm{~cm}$ ).

e. Tulangan utama pada kolom dibengkokkan ke arah pondasi dan balok sepanjang 40D guna memenuhi panjang penyaluran untuk bangunan tahan gempa.

f. Untuk meningkatkan kesatuan elemen dan mencegah agar dinding tidak lepas saat terjadi gempa maka angkur dipasang dari kolom ke dinding.

g. Kolom diangkurkan pada pondasi.

h. Sengkang memiliki seismic hook (bengkokan) sepanjang 6D (baca pembengkokan tulangan) dan diameter tulangan sengkang minimal yang digunakan adalah 8 $\mathrm{mm}$.

2) Pekerjaan Balok

a. Ukuran minimal balok $15 \times 20 \mathrm{~cm}$.

b. Tulangan utama balok minimal adalah 4D10.

c. Sengkang minimal adalah diameter $8 \mathrm{~mm}$.

d. Sengkang memiliki seismic hook (kait)

e. Panjang penyambungan tulangan atau panjang kait tulangan balok ke kolom adalah 40D.

3) Pekerjaan Pasangan Bata 
a. Pertemuan dinding siku.

b. Dinding bata diangkurkan ke kolom setiap jarak $30 \mathrm{~cm}$

c. Bata/batako dipasang selang-seling.

d. Spasi bata 8-15 $\mathrm{mm}$.

e. Kualitas bata yang digunakan sama.

f. Bata dibasahi sebelum dipasang.

g. Pemasangan angkur/penjangkaran antara kusen pintu dan jendela dengan dinding.

4) Pemasangan Dinding Ampig

a. Tulangan utama yang digunakan memiliki diameter minimal $12 \mathrm{~mm}$.

b. Diameter sengkang minimal adalah $8 \mathrm{~mm}$.

c. Jarak sengkang $<15 \mathrm{~cm}$.

d. Panjang penyaluran tulangan yaitu 40 D.

5) Rangka Atap

a. Rangka atap atau kuda-kuda atap diikat pada rangka struktur yaitu balok dan kolom.

b. Sambungan kuat dengan cara diberi baut dan pelat pengikat.

c. Diameter baut dan jangkar yang digunakan minimal $12 \mathrm{~mm}$.

d. Atap yang digunakan dari bahan yang ringan.

6) Penutup Atap

a. Material atap yang digunakan berbahan ringan.

b. Atap dipasang dengan kuat.

c. Sekrup atau paku digunakan untuk menyambung material atap.

Persentase kualitas konstruksi berdasarkan karakteristik material dengan persyaratan tahan gempa dapat dilihat pada Tabel 3 . Berdasarkan Tabel 8 dapat disimpulkan bahwa berdasarkan kesesuaian material dengan persyaratan tahan gempa berada pada kualitas cukup baik dengan persentase rata-rata 97,14\%.

Tabel 3. Karakteristik Kualitas Material

\begin{tabular}{clc}
\hline No. & \multicolumn{1}{c}{ Kecamatan } & $\begin{array}{c}\text { Kualitas Material } \\
(\%)\end{array}$ \\
\hline 1 & Medan Johor & 100 \\
\hline 2 & Medan Tembung & 93,64 \\
\hline 3 & Medan Perjuangan & 94,48 \\
\hline 4 & Medan Timur & 100 \\
\hline 5 & Medan Helvetia & 93,78 \\
\hline 6 & Medan Sunggal & 100 \\
\hline 7 & Medan Denai & 95,42 \\
\hline & Rata-rata & 97,14 \\
\hline
\end{tabular}

Hasil analisis karakteristik kesesuaian material dengan persyaratan tahan gempa disajikan sebagai berikut :

1) Pasir
a. Berasal dari sungai/darat
b. Bebas dari tanah/lumpur
c. Bebas dari bahan organik

2) Kerikil
a. Berasal dari sungai/darat
b. Bebas dari tanah/lumpur
c. Bebas dari bahan organik seperti daun, kayu dan lain-lain
d. Diameter $1-2 \mathrm{~cm}$

3) Semen
a. Portland semen
b. Tidak mengeras
c. Kering
d. Dengan kemasan 40/50 kg
e. Tidak tercampur bahan material lain
f. Warna seragam

4) Air
a. Bersih
b. Tidak berwarna dan tidak berbau
c. Tidak mengandung minyak, asam, alkali atau bahan lain yang dapat merusak beton

d. Dapat diminum

5) Batu Bata
a. Dibakar sempurna
b. Rata/tidak melengkung
c. Tidak mudah pecah atau retak
d. Ukuran seragam
e. Sudut-sudutnya tidak gompal/rusak
f. Ukuran minimum $20 \times 10 \times 5 \mathrm{~cm}$

6) Batako, Conblock
a. Terbuat dari adukan beton
b. Sudut-sudutnya gompal/rusak
tidak
c. Tidak retak-retak

7) Kayu
a. Kering
b. Lurus
c. Tidak banyak mata kayu
d. Anti rayap

8) Batu Belah
a. Ukuran seragam mungkin
b. Permukaan kasar/tidak halus

9) Besi Tulangan
a. Ukuran seragam
b. Memenuhi syarat-syarat yang berlaku
c. Tidak karatan
d. Lurus
e. Diameter sesuai perencanaan 


\section{Analisis Karakteristik Rumah Di Kota Medan TerhadapPedoman Teknis Rumah Dan Bangunan Gedung Tahan Gempa}

Berdasarkan hasil analisis karakteristik kualitas elemen struktur dengan persyaratan tahan gempa, kualitas struktur pondasi dan perkuatannya berada pada kualitas baik dengan persentase rata-rata $70,57 \%$ dan kelengkapan struktur sloof, balok dan kolom serta proporsi campurannya juga berada pada kualitas baik dengan persentase 67,60\%. Perbandingan persentase antara keduanya signifikan, sehingga dapat disimpulkan karakteristik konstruksi rumah dikota medan sudah baik.

\section{Simpulan}

Berdasarkan hasil survey, observasi dan analisis data terhadap persepsi penghuni dan struktur bangunan komplek perumahan di kota Medan maka dapat ditarik beberapa simpulan sebagai berikut :

a. Karakteristik rumah di kota Medan adalah rumah semi permanen dan rumah permanen. Rumah semi permanen merupakan rumah kayu melayu deli dan rumah panggung melayu deli 2 lantai yang telah di modifikasi. Rumah semi permanen ini tinggal hanya beberapa saja yang masih dilestarikan oleh pemiliknya. Rumah permanen merupakan rumah tembokan 1 lantai, 2 lantai dan rumah mewah.

b. Pada rumah semi permanen penutup atap umumnya seng sangat jarang yang masih menggunakan rumbia (daun nipah) namun ada juga yang menggunakan genteng. Pondasi rumah semi permanen merupakan pondasi tiang kayu yang ditancapkan kedalam tanah namun ada juga yang menggunakan pondasi tapak. Pada rumah permanen penutup atapnya sebagian besar menggunakan genteng namun ada yang menggunakan atap metal. Pondasinya menerus dengan bahan batu kali dan sudah menggunakan balok sloof.

c. Kualitas elemen struktur berdasarkan persepsi penghuni rumah berdasarkan persyaratan tahan gempa adalah penutup atap rata-rata $88,74 \%$. Untuk elemen perkuatan struktur yaitu pondasi rata-rata sebesar $70,57 \%$ dan kelengkapan struktur sloof, balok dan kolom serta proporsi campurannya rata-rata $67,60 \%$. Kualitas dinding rata-rata $77,14 \%$.
Daftar Pustaka

Basuki, Achmad, 2009, Menilik Kualitas Bangunan, http://achmadbasuki.wordpress.co $\mathrm{m}$

Bambang, 2011, Desain Fasad Rumah Ala Real Estate, Jakarta: Griya Kreasi

Direktorat Jendral Cipta Karya, 2006, Pedoman Teknis Rumah dan Bangunan Gedung Tahan Gempa, Jakarta: Dinas Pekerjaan Umum.

Pangestu, P., Wibowo, S., 2007, Analisa Kepuasan Pengembang Terhadap Kualitas Konstruksi pada Rumah Kelas Menengah di Surabaya, Petra Christian University Library| library@petra.ac.id.

Undang-Undang Republik Indonesia No. 4 tahun 1992, (1992). Tentang Rumah dan Permukiman.

Undang-Undang Republik Indonesia No. 1 tahun 2011, (2011). Tentang Rumah dan Kawasan Permukiman.

Natawidjaja, D. \& Triyoso, W. (2007). The Sumatran fault zone - from source to hazard, Journal of Earthquake and Tsunami, 1(1), hal. 21-47.

Sieh, K., \& Natawidjaja, D. (2000). Neotectonics of the Sumatran fault, Indonesia. Journal of Geophysical Research. 105, 28,295-28,326.

Soetardjo, Untung, M., Arnold, E. P., Soetadi, R., Ismail, S., \& Kertapati, E. K. (1985). In Series on seismology, volume V: Indonesia. (Arnold, E.P., ed.), Southeast Asia association of seismology and earthquake engineering (SEASEE). Denver: USGS press.

Supriani, F. , 2011, Analisa Tipikal Rumah Real Estate di Kota Bengkulu dan Kesesuaian dengan Rumah Tahan Gempa, Inersia, Jurnal Teknik Sipil, Universitas Bengkulu.

Surowiyono, Tw, Tutu., 1996, Dasar Perencanaan Rumah Tinggal, Pustaka Sinar Harapan, Jakarta. 